\title{
Waste-Free Use of Quail Meat in Semi-Finished Food Production
}

\author{
A.L. Dashtoyan, K.H. Gharibyan, H.S. Sargsyan, A.A. Baghdasaryan \\ Armenian National Agrarian University \\ annad-1976@mail.ru, kristinegharibyan@gmail.com, sargsyanhayk590@gmail.com, agapikaren@gmail.com
}

\section{A R T I CLE IN FO}

\section{Keywords:} quail meat, semi-finished product, cutlet, buckwheat flour, innovation

\begin{abstract}
A B S T RA C T
Semi-finished food production from the meat raw material has gained a broad application in the consumer market due to ease of its production organization, digestibility, fast consumption, long shelf life and safety.

The research considers the development trends in cutlet (semi-finished meat product) manufacturing technologies via quail meat and plant-based filler application.

The study aims to improve cutlet production technology through replacing the chicken meat with quail meat and supplementing buckwheat flour.

A new cutlet production technology and recipe has been developed and their relevance has been proved.
\end{abstract}

\section{Introduction}

Semi-finished meat products are the most widely consumed food products due to their flavor properties, long shelf life and high nutrition value. In Armenia, a wide range of semi-finished products are manufactured mainly from chicken meat, beef and pork. Nowadays, the issue of developing waste-free technologies is faced by all meat processing organizations of the Republic of Armenia. The new developed technology via using quail meat in cutlet production is related to the waste-free production, since it is also planned to prepare cutlet farce through chopping the bones of the quail meat carcass into pieces. The quail meat is endowed with rich and succulent flavor, as well as with high nutrition value. It is recommended for the application in the dietetic nutrition. The quail meat exceeds the chicken meat, pork and beef in its wholesomeness, flavor and dietary qualities. The systematic use of the quail meat in medicine promotes the treatment of diseases in gastrointestinal tract, liver, kidney, cardiovascular and respiratory system (Pryanishnikov and Miklyashevsky, 2001).

The origin of buckwheat is the Northern India, where it is also called black rice. Usually there are two types of buckwheat: Common and Tartary buckwheat. The hull of the Tartary buckwheat is thicker, while the grain is smaller. The Common buckwheat is usually winged and wingless. The Common buckwheat has a widespread 
application in the food sector, while the Tartary buckwheat is used both in forage production and soil cultivation as a green manure. Buckwheat contains a great amount of iron, as well as calcium, potassium, phosphorus, iodine, zink, molybdenum, cobalt, vitamins $B_{1}, B_{2}, B_{9}, P P$ and Vitamin $E$. Flour can be produced from buckwheat, which is not used in bread baking due to lack of gluten, and if so, it is mixed with wheat flour. Buckwheat, its flour and the food varieties produced from buckwheat are regarded as foodstuffs of rather high nutrition value. Buckwheat flour is easily digested and dietetic with high flavor properties.

\section{Materials and methods}

The aim of the current work is to develop and produce a new variety of semi-finished food product using the quail meat with its bone tissue supplemented with plantbased protein. Throughout the research the chemical composition (Table 1) and functional properties of the quail meat and its application in the semi-finished food production has been studied; besides, semi-finished food product manufacturing technology via the mixture of quail meat and buckwheat has been developed. By using the bone tissue of the quail meat in the farce of semi-finished product, the waste-free production technology has been ensured and the food product has been supplemented with micro-nutrients, such as phosphorus and calcium.

Table 1. The chemical composition of the quail meat*

\begin{tabular}{|c|l|c|}
\hline $\mathbf{n} / \mathbf{n}$ & Name of the component & Amount \\
\hline 1 & Proteins, $g$ & 18.2 \\
\hline 2 & Fats, $g$ & 17.30 \\
\hline 3 & Carbohydrates, $g$ & 0.4 \\
\hline 4 & Vitamin A, $m g$ & 0.07 \\
\hline 5 & Vitamin $\mathrm{B}_{1}, m g$ & 0.1 \\
\hline 6 & Vitamin $\mathrm{B}_{2}, m g$ & 0.26 \\
\hline 7 & Vitamin PP, $m g$ & 8.3 \\
\hline 8 & Vitamin $\mathrm{B}_{9}, m g$ & 0.07 \\
\hline 9 & Humidity, $\%$ & 70.03 \\
\hline 10 & Na, $m g$ & 35 \\
\hline 11 & K, $m g$ & 257 \\
\hline 12 & Ca, $m g$ & 21 \\
\hline 13 & Mg, $m g$ & 25 \\
\hline 14 & F, $m g$ & 190 \\
\hline 15 & Fe, $m g$ & 3.20 \\
\hline 16 & Energy value & $230 \mathrm{kcal}$ \\
\hline
\end{tabular}

*Composed by the authors.
The cutlets are usually produced through the following technology:

\section{Preparation of the quail meat}

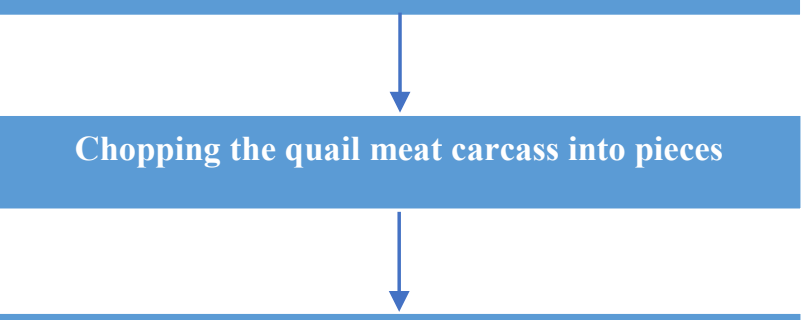

Grinding through the meat grinder $(2-3 \mathrm{~mm})$

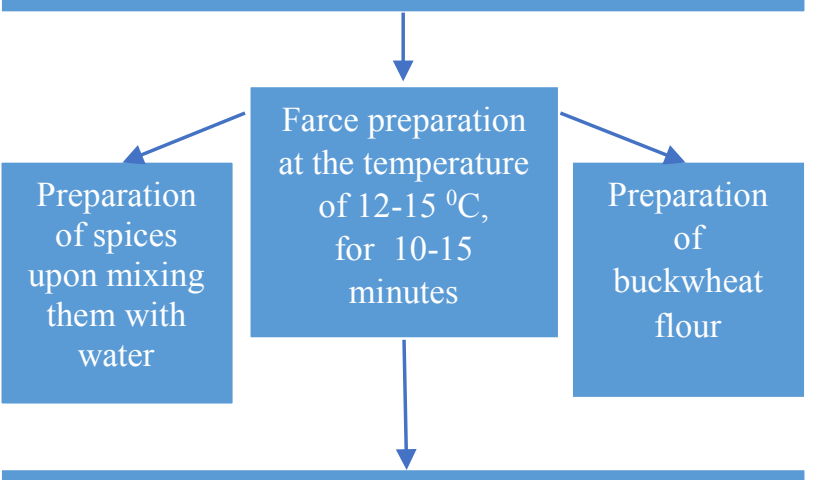

Forming and breading

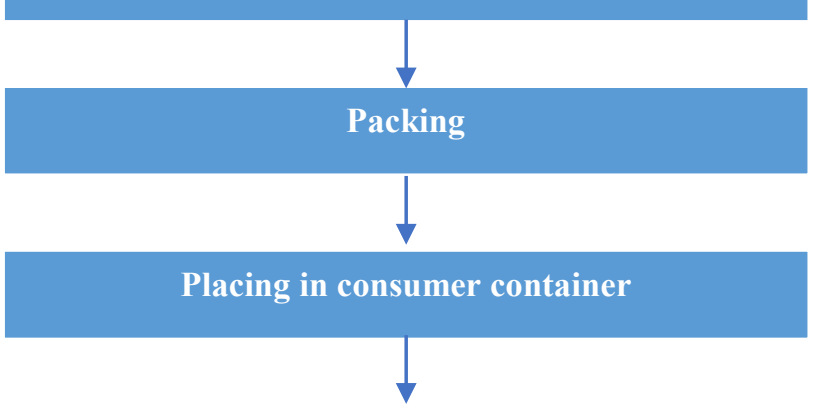

Chilling (at $0-1{ }^{0} \mathrm{C}$ or at $-0.5--44^{\circ} \mathrm{C}$, until the temperature reaches $0-4{ }^{0} \mathrm{C}$ in the muscle depth)

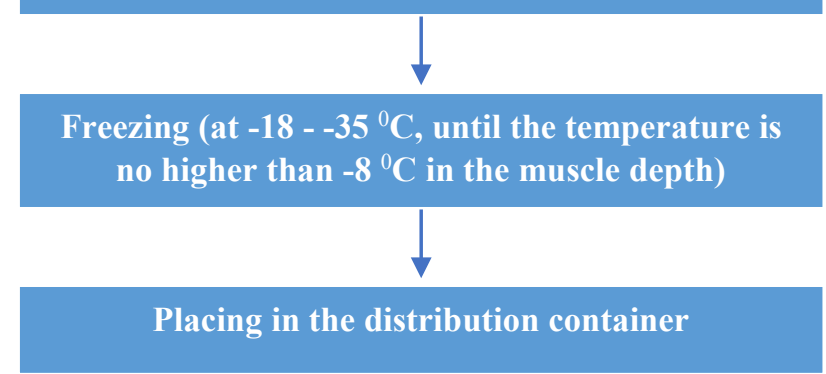

Diagram. The technological scheme of cutlet production with buckwheat flour and quail meat (composed by the authors) 
A new cutlet recipe via the use of quail meat and buckwheat flour, as well as the technological scheme (Diagram) of its production has been developed by our research group and the experimental sample has been produced in the laboratory of the chair of "Animal-Based Foodstuff Processing Technology”, ANAU.

The quail meat, its farce in different production phases and ready-to-eat cutlet have served as a study subject for this investigation. Since the studies are conducted for the first time in Armenia, we have used homemade cutlets as a control variant according to GOST P 52675-2006. First, the quail meat with the bone tissue was investigated considering that the quail meat carcass is the only meat variety among the poultry meat, the bone tissue of which is highly resistant to various pathogenic diseases. Thus, one of our research objectives is also to process such semifinished meat product which can be recommended to the consumers irrespective of age and health group (Rogov, et al., 1989).

Based on some investigations new cutlet recipe has been developed, which is introduced in Table 2. According to the required standard the recipe is applied per $100 \mathrm{~kg}$ bland raw material.

Table 2. New cutlet recipe with quail meat and buckwheat flour*

\begin{tabular}{|c|l|c|}
\hline $\mathbf{n} / \mathbf{n}$ & Name of raw material & $\begin{array}{c}\text { Quantity } \\
\mathbf{k g}\end{array}$ \\
\hline 1 & Quail meat with bones & 72 \\
\hline 2 & Dry cow milk & 20 \\
\hline 3 & Egg & 3 \\
\hline 4 & Breadcrumb & 4 \\
\hline 5 & Wheat flour & 1 \\
\hline 6 & Edible salt & 1.2 \\
\hline 7 & Black and white pepper & 0.05 \\
\hline
\end{tabular}

*Composed by the authors.

The finished product output makes $115 \%$, while the output of finished product per the bland raw material, particularly that of in the control variant makes $100 \%$.

The cutlet produced from the quail meat has been studied per its humidity, proteins, fat, mineral substances, plantbased fillers, edible salt contents. The energy value of the new semi-finished product has been estimated. The readyto-eat cutlet has been subjected to degustation and the food product has been assessed through 30-point scale system scoring 27 points, which is considered an excellent index for the semi-finished food products (Table 3).

All experiments have been conducted with three replications and the arithmetic mean has been assumed as the final outcome which is introduced in the respective Tables 4, 5.

Table 3. Organoleptic indices of the cutlets made from the quail meat carcass and buckwheat flour*

\begin{tabular}{|c|c|}
\hline Indicator & Description \\
\hline Appearance & $\begin{array}{c}\text { Round or oval, with evenly breaded } \\
\text { surface, without breaks }\end{array}$ \\
\hline Taste and flavor & $\begin{array}{c}\text { Fit to high-quality raw material with } \\
\text { weak flavorings }\end{array}$ \\
\hline *Composed by the authors. \\
\hline
\end{tabular}

\section{Results and discussions}

As it is indicated in Table 4, the humidity amount in the experimented sample is lower than in the control sample. This is due to the fact that the buckwheat flour and crushed bony raw material included in the cutlet recipe, are endowed with high water absorption capacity and have bound (absorbed) the excess humidity, increasing the output of finished product and prolonging the shelf life of the experimented food product. The surplus of protein amount (by $9.1 \%$ ) in the experimented sample again comes to prove the efficiency of the quail meat carcass, plant-based protein and buckwheat flour application.

Table 4. The physicochemical indicators of the cutlets made from the quail meat carcass and buckwheat flour*

\begin{tabular}{|l|c|c|c|c|}
\hline $\begin{array}{c}\text { Name } \\
\text { of the sample }\end{array}$ & $\begin{array}{c}\text { Humidity } \\
\%\end{array}$ & $\begin{array}{c}\text { Protein } \\
\%\end{array}$ & $\begin{array}{c}\text { Fat } \\
\%\end{array}$ & $\begin{array}{c}\text { Mineral } \\
\text { substances } \\
\text { (including } \\
\text { edible salt) } \\
\text { \% }\end{array}$ \\
\hline $\begin{array}{l}\text { Control } \\
\text { sample }\end{array}$ & 68.2 & 10.3 & 18.1 & 3.4 \\
\hline $\begin{array}{l}\text { Experimented } \\
\text { sample }\end{array}$ & 66.4 & 19.4 & 6.1 & 8.1 \\
\hline
\end{tabular}

*Composed by the authors. 
According to Table 5, the fat content in the control sample lags behind that of experimented sample by $12 \%$, which is accounted for the chemical composition and overall characteristics of the quail meat carcass and buckwheat flour. Due to the high protein content, the experimented sample is easily digested and can be recommended to the patients sick with cardiovascular and diabetic diseases (Skurikhin and Volgarev, 1987).

Table 5. Energy value estimation of the cutlets made from the quail meat carcass and buckwheat flour*

\begin{tabular}{|c|c|c|c|}
\hline $\begin{array}{c}\text { Name of the } \\
\text { sample }\end{array}$ & $\begin{array}{c}\text { Protein } \\
\%\end{array}$ & $\begin{array}{c}\text { Fat } \\
\%\end{array}$ & $\begin{array}{c}\text { Energy value, } \\
\text { kcal }\end{array}$ \\
\hline Control sample & 10.3 & 18.1 & 204.1 \\
\hline $\begin{array}{l}\text { Experimented } \\
\text { sample }\end{array}$ & 19.4 & 6.1 & 132.5 \\
\hline
\end{tabular}

Apart from manufacturing high-quality food product our aim is also to reduce the production costs and, to some extent, the production duration based on the circumstance, that there is no deboning process as a separate stage in the cutlet production. So, the raw stuff is used with the bones, which increases the qualitative and organoleptic indicators of the manufactured food product.

\section{Conclusion}

New type of semi-finished product has been developed and produced by applying bone tissue of quail meat and saturating it with plant-based protein and buckwheat flour.

Based on the conducted analyses and estimations the following conclusions can be drawn:

For the first time the chemical composition of the quail meat, its functional properties and application in the semifinished food production has been researched.

Upon the application of quail meat bone tissue in the farce of semi-finished product the waste-free production has been ensured and the food products have been supplemented with macronutrients, such as phosphorus and calcium.

The recipe of semi-finished product via the mixture of quail meat and buckwheat flour and the production technology has been developed for the first time, and it has been proved that their application promotes the increase of finished product yield by $15 \%$.

The new product has been investigated per its organoleptic and physicochemical properties. It has been proved that the humidity content in the new product is reduced; as a result its shelf life and protein content has increased due to quail meat and buckwheat flour application at the same time making the product easily digestible and nutritious.

The energy value of the mentioned product has been also estimated, which makes $132.5 \mathrm{kcal}$.

The aforementioned conclusions provide a ground to state that the manufactured food product is endowed with high functional and technological properties and that it can be introduced in the production and also be recommended to the patients suffering from cardiovascular and diabetic diseases as dietary and health-promoting meat product.

\section{References}

1. GOST P 52675-2006. National Standard of Russian Federation. Semi-Prepared Meat and Meat-Contained Products.

2. General Specifications. Rogov, I.A., Zabashta, A.G., Aleksakhina, V.A., Titov, E.I. (1989). Technology and Equipment for Sausage Production. - M.: Agropromizdat, - $351 \mathrm{p}$.

3. Skurikhin, I.M., Volgarev, M.N. (1987). The Chemical Composition of Food Products: Book 1: Reference Tables of the Content of Basic Nutrients and the Energy Value of Food Products, - 2nd Ed. Revised and Add. - M .: "Agropromizdat", - 224 p.

4. Pryanishnikov, V.V., Miklyashevsky, P. (2001). Dietary Fiber Vitazel is a Functional Product. Materials of the International Scientific Conference "Functional Food Products", Moscow. 